\title{
1 ON SOME ORIENTAL ELEMENTS IN OLD NOVGORODIAN AND OTHER OLD RUSSIAN DIALECTS
}

\author{
KLÁRA AgYAGÁSI \\ University of Debrecen, Faculty of Arts, Institute of Slavic Studies \\ 4002 Debrecen, Pf. 400, Hungary \\ e-mail: klara.agyagasi@gmail.com
}

7 The author is aiming to interpret the historical connection between Old Russian kamka and Old

8 Novgorodian xamz 'textile of silk damask'. She comes to the conclusion that the former is a borrow-

9 ing from East Old Turkic qamqï, while the latter is a loan from West Old Turkic xamï. Both Old

10 Turkic words are of Chinese origin.

11 Key words: Turkic-Russian language contact, Volga Bulgarian, West Old Turkic loanwords in Rus12 sian, Wanderworts of Oriental origin.

13

14 The focus of the present paper is on the word meaning 'silky Chinese textile; variegated 15 woven linen; damask', which has been known in a variety of forms in East Old

16 Turkic and Old Russian sources since the 12th century onward, as well as in modern

17 Turkish and its regional dialects, while its derived forms can be traced in regional dia18 lects of Russian. This word is found in Russian, designating an expensive trade item 19 brought from far away, having been borrowed into Old Russian from Old Turkic, 20 where, however, it was an earlier borrowing from the Orient. It is enough to call back 21 the history of the Russian words žemčug 'mother-of-pearl' (cf. Dobrodomov 1966, 22 pp. 57-64; Menges 1970, pp. 94-100; Róna-Tas-Berta 2011, pp. 402-404) or kniga 23 'book' (cf. Kniezsa 1955, p. 872; Dobrodomov 1971; Komoróczy 1976, pp. 28-29; 24 Trubačev 1987, pp. 203-204; Agyagási 1994; Róna-Tas-Berta 2011, pp. 590-593). ${ }^{1}$

25 However, while in these examples the source dialect of Old Turkic can be identified 26 with reasonable certainty only as Bulgar Turkic (or, using a more modern designation,

\footnotetext{
${ }^{1}$ For the history of research regarding Oriental elements of the Russian lexicon until 1970, see Dobrodomov - Romanova (1970), for the words of Turkic origin from later on, see Dobrodomov (1976; 1985); Šipova (1976); Vásáry (2013; 2016); Agyagási (2015).
} 
1 the Ogur dialect of West Old Turkic), in the case of the word under investigation I want 2 to argue for multiple sources of the Russian variants of the word.

3 The history of the Russian word kamka was first mentioned by Ogienko $4(1915 / 2015$, p. 29) in the Russian literature on lexicology, who lists it together with 5 words that, according to him, were borrowed into Russian from Persian at various 6 times, but he does so without providing the Persian form in question. Šipova (1976, 7 pp. 156-156) discusses the historic occurrences of the Russian word kamka, specifi8 cally detailing those from the 18th century, quoting Ogienko's opinion about the Per9 sian origin of the word, but without expressing her individual stance regarding the 10 details of the borrowing process. The second, Russian language edition of Vasmer's 11 dictionary (Fasmer 1986/2, pp. 174-175) states that the source of the Russian word 12 could be any of the known Turkic languages, where the word can be regarded to be 13 of Chinese origin. But he does not provide the original Chinese source of the word.

14 The geographical distribution of the forms meaning 'damask' and the etymol15 ogically likely related variant forms were analysed in earlier Orientalist research. ${ }^{2}$

16 The earliest occurrence of the word is in Arabic language sources: Hurdāobih (8th cen17 tury) kimhāa 'soie damassée'; Balāourī (892) kīmhāw 'soie damassée'; Ṭabarī (10th 18 century) kamhāna 'pannus sericus' (cf. Doerfer 1967, p. 603). After a hiatus of a few 19 centuries, it occurs in Persian: kimhă (1401) 'Brokat der Arten Nasīğ' (Doerfer 1967, 20 p. 603). In the correspondence of the emperors of the Ming dynasty and Timurid Šāh21 ruh it is found in two variant Persian forms with two different meanings: kamha or $22 k a m h \bar{a} b$ 'pannus pictus unius coloris', and kimh $\bar{a}$ or kimh $\bar{a} b$ 'pannus pictus versi23 color; silk worked with gold or silver flowers, brocaded silk, brocade, velours' (Doer24 fer 1967, p. 604).

25 Beginning with the early 14th century (following Marco Polo's journey to 26 China), it appears in several languages of mediaeval Europe (French camocas and its 27 variants, Italian сатисса, English camaca, mediaeval Latin camoca, Spanish camo28 can, camucan 'textile of silk damask woven in all colours, sometimes with stripes of 29 gold and silver, the designs mainly birds' (Pelliot 1959, pp. 145-146). It is known in

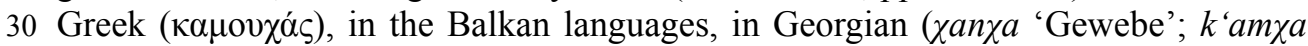
31 'Art Seidengewebe'), and from the 18th century onward variants of the word also 32 appeared in India (Hindi kamkhvāb, Bengali kimkhvāb 'gold brocade': Pelliot 1959, 33 pp. 145-147), from where it was borrowed into Tibetan and Malay (Doerfer 1967, 34 pp. 604-605).

35 As can be seen, the various variants of the word are found all over Eurasia, in 36 a web of borrowing processes acting in various directions. All variants of the word 37 can be traced back to two forms: kimha and kamha $\bar{a}$, and the word may or may not 38 have a syllable-final $b$ at the end. Both Pelliot (1959, p. 147) and Doerfer (1967, pp. 39 604-605) concluded that the ultimate source of these forms is Chinese. After a lengthy 40 discussion, criticising and finally rejecting the results of earlier Sinologist research 41 regarding Chinese words meaning 'damask, brocade, silk', Pelliot opts for Y. Yule's

\footnotetext{
${ }^{2}$ I am grateful to Imre Hamar and Gábor Kósa for making the Orientalist literature cited below available to me.
} 
1 explanation as the most plausible. Accordingly, the forms borrowed into the various

2 languages of the Eurasian region are closest to the Chinese expression chin-hua

$3\left(* k i z m-\chi^{w} a\right)$ 'gold flower', which had gone through a series of semantic changes

4 since the 9th century. The word became the designation of valance in Southern China,

5 where Arabic and Persian merchants became familiar with it. Following its Chinese

6 pronounced form, they probably wrote it down as kimhāw (Pelliot 1959, pp. 149-

7 150). However, the Cantonese pronunciation of the first part of the compound was

$8 \mathrm{kam}$ (Pelliot 1959, p. 148), which form must have found its way to the west through

9 other merchants. This would explain the two parallel phonetic variants of the word in

10 the languages of Eurasia.

11 Both researchers attempted to provide a detailed explanation for the historical

12 relationship of the forms occurring in many languages of the enormous Eurasian

13 region. They agreed that the main mediatory language was Persian, which could have

14 transmitted both phonetic variants. They also agreed that the word was borrowed into

15 Turkic and Slavic languages via Persian, but Pelliot also provides a detailed train of

16 thought as an explanation: in his opinion, borrowing via Persian had to be posited

17 because there was not a single Old Turkic source, beginning with Kāš

18 Uygur to the Mongol Period, which historically documented the result of the direct 19 borrowing from Chinese into Turkic and from Turkic into Slavic.

20 At this juncture, I would like to return to the original train of thought of Pel-

21 liot's paper to specify Pelliot's stance, since after his work had been published, an

22 East Old Turkic written source using Uygur writing (from the 12th-14th centuries)

23 was found in which the word in question occurred. It was first published in the Drev-

24 netjurkskij slovar', ten years after Pelliot's work. Also, the Old Novgorodian birch

25 bark charter has become widely known only recently, which contains the investigated

26 word dating from the 14th century and can be directly connected with the Old Turkic

27 variant. The data are as follows:

28 Turkic data:

29 East Old Turkic (12th-14th centuries) qamqï 'kamka, šelkovaja materija' (DTS p. 30 416); Sayay kamgï 'kamka, kitajskaja šelkovaja materija' (Radlov 1893-1911, II, p.

31 490); Alt., Tel., Kir. kamka 'id.' (Radlov ibid.); Kirg. kamka 'kitajskij šelk' (Yudahin Missing from the 1966); Crimean Tatar kimxa'damast, šelkovaja materija' (Radlov II, p. 1405); Kazan References. $\quad$ Tat. kamka (ust.) 'kamka' (TRS 1966, p. 219); Bashk. qamqa 'raznovidnost' kitaj34 skogo šelka' (Uraksin 1996, p. 344); Turkish kemha 'rod šelkovoj tkani' (TRS 1977, 35 p. 531).

36 Slavic data:

37 Old Novgorodian (cca. 1310-1330) xamz 'polotno' (Zaliznjak 2004, p. 541); Old 38 Russian (1486) KAIHKA ‘šelkovaja cvetnaja tkan’ s uzorami’ (Sreznevskij 1989, I, pp. 39 1186-1187); (15th-16th century 1472) KAIHKA 'šelkovaja cvetnaja uzorčataja tkan", 40 (Filin 1980, p. 48); Russian dial. хамовник (star.) 'tkač, polotnjanščik, skatertnik'; 41 хамовное (дело) 'tkackoe, polotnjanoe i branoe' (Dal' 1881/1989 Vol. IV, p. 542) 
Polish (15th-17th centuries) kamcha 'nazwa drogiej materji, adamaszku' 2 (Brückner 1957, p. 215); bolg. kámúha 'edinstroj koprinjana tkan' (Gerov 1976, p. 3 344).

4

The East Old Turkic word qamqï can be the directly borrowed variant of the 6 Chinese $\operatorname{chin}\left({ }^{*} k i \partial m-\chi^{w} a\right)$ (pronounced in the Cantonese way) plus $c h{ }^{\prime} i\left({ }^{*} k^{\prime} j i e\right)^{3} \mathrm{com}$ 7 bined as a compound, with the meaning 'brocade'. This word, however, was borrowed 8 directly not only into East Old Turkic but also into West Old Turkic. Although the lat9 ter is not documented in early written sources, the speakers of this variety of Old 10 Turkic got into direct contact with several communities speaking a wide range of 11 other languages between the 5th century and the Mongol invasion of Europe. The 12 lexical items borrowed from these languages were mostly retained in the languages 13 of the communities they were in contact with. The most detailed source of early West 14 Old Turkic is the group of Old Turkic loanwords in the Hungarian language, recently 15 treated by Róna-Tas and Berta (2011) in detail. Volga Bulgars achieved a prominent 16 role among the speakers of West Old Turkic varieties. From the 10th century onward 17 they controlled the east-west river trade, soon founded their empire, and traded with 18 various peoples themselves, among them the merchants of the Old Novgorodian city 19 state. ${ }^{4}$ However, since in Chuvash, the language of the only direct descendants of the 20 Volga Bulgars still living today, this word has not been preserved, the West Old Turkic 21 equivalent of East Old Turkic qamqi should be sought in the lexicon of the Old Nov22 gorodian dialect.

23 In the West Old Turkic equivalent of the 12th-13th-century East Old Turkic 24 form qamqï a $q$ - $>\chi$ - change must have taken place, since this change started already 25 in the 7th century (for details, see Róna-Tas-Berta 2011, pp. 1100-1101). The $q$ of 26 the second syllable, however, became voiced and soon underwent spirantisation $(q>$ $27 \dot{g}>\gamma$ ), and finally it was dropped $(\gamma>\varnothing)$. The first part of the process (i.e. the secon28 dary voicing of the non-first syllable $-q$ ) is traceable in one Volga Bulgarian loan29 word in Old Russian: Volga Bulgarian buraq 'beer' > *burag $>$ buray $\rightarrow$ Old Russian 30 brraga 'id.', cf. East Old Turkic boza 'a kind of beer' (Agyagási 2010). The deletion 31 of the voiced spirant is exemplified by an early West Old Turkic loanword in Hungar-


33 bér 'wage, rent'), cf. East Old Turkic bergü 'something which ought to be given, gift, 34 tax' (Róna-Tas-Berta 2011, pp. 115-118).

35 The word-final $-\ddot{i}$ of the form qamqï could not be preserved when borrowed 36 into Russian for morphological reasons: after having been borrowed, the Turkic word 37 had to fit one of the Old Russian noun classes. However, the Old Russian noun de38 clension system did not have a class for hard $i$-stems. The word occurring on the cited 39 birch bark charter has a $-u$ final genitive partitive case marker, which means that the 40 West Old Turkic/Volga Bulgarian variant was adopted by the speakers of the Old

\footnotetext{
${ }^{3}$ In earlier literature, Philips mentioned the existence of such a lexical structure in Chinese (cf. Pelliot 1959, p. 148).

${ }^{4}$ Contacts between Volga Bulgarians and Old Novgorodians were also mentioned oftentimes in the 1st Novgorodian Annals.
} 
1 Novgorodian dialect as a masculine $*-\breve{u}$ stem, monosyllabic, Class IV noun. Consid2 ering all this, the history of the borrowing of the West Old Turkic (Volga Bulgarian) 3 word can be reconstructed as follows:

$4 \quad$ West Old Turkic *qamqï 'silk damask' > * $\chi a m \dot{g} \ddot{i}>*^{*} \chi a m \gamma \ddot{i}>*^{*} \chi a m \ddot{i} \rightarrow$ Old 5 Novgorodian $\chi a m ъ$ 'damask'.

6 The Old Novgorodian noun, however, did not remain isolated: this Russified 7 stem served as a base for the word xamovnik 'weaver', a nomen agentis derived with 8 the Russian $o v+n i k$ denominal complex suffix, and the adjectival equivalent of the 9 word was also created by attaching the -ov possessive adjectival derivational suffix to 10 the stem.

11 The variants with the phonological form kamka, attested in other Old Russian 12 dialects from the 15th century onward, were borrowed into Russian either from East 13 Old Turkic or from Persian. If the word is regarded as a later borrowing from the East 14 Old Turkic qamqï, the word-final $-\ddot{i}$ was replaced by the feminine $-a$ ending, again 15 for morphological reasons. However, if the Persian form kamha $\bar{a}$ was the source of the 16 Russian word, a replacement of $-h$ with $-k$ in the second syllable has to be posited.

8 Agyagási, K. (1994): Weitere Beiträge zur Aufdeckung eines internationalen Wanderwortes (Das 19 Wort 'Buch' im Volgagebiet). In: Baldauf, I. - Friedrich, M. (Hrsg.): Bamberger Zentral20 asienstudien. Konferenzakten ESCAS IV. Bamberg 8-12. Oktober 1991. Berlin, pp. 29-36. 21 Agyagási, K. (2010): Loanwords as Data in Historical Linguistics: An Areal Linguistic Study. In: 22 Agyagási, K. (ed.): Data in Historical Linguistics. Münster (A special issue of Sprachtheorie 23 und germanistische Linguistik, 22.2), pp. 197-222.

24 Agyagási, K. (2015): K ètimologii čalyj 'seryj - o masti lošadi' s pozicii areal'noj lingvistiki. Slavi$25 \quad c a$ Vol. 44, pp. 31-36.

26 Brückner, A. (1957): Słownik etymologiczny języka polskiego. Kraków.

27 Dal', V. (1881/1989): Tolkovyj slovar'živogo velikorusskogo jazyka. 4 vols. Moskva.

28 Dobrodomov, I. G. (1966): O metodah issledovanija drevnejših tjurkizmov v sostave russkogo slo29 varja (K istorii slova žemčug). Izvestija Akademii nauk SSSR. Serija literatury i jazyka Vol. $30 \quad 25$, No. 1, pp. 57-64.

31 Dobrodomov, I. G. (1971): Kniga. Russkaja reč’ No. 5, pp. 83-91.

32 Dobrodomov, I. G. (1976): Voprosy hronologii tjurkskih zaimstvovanij v slavjanskih jazykah. So33 vetskaja tjurkologija No. 6, pp. 24-37.

34 Dobrodomov, I. G. (1985): Bulgarskie zaimstvovanija v drevnerusskom i drugih slavjanskih jazy35 kah kak istočnik dlja problemy ètnogeneza čuvašej. In: Pavlov, I. P. (red.): Voprosy istorii 36 čuvašskogo jazyka. Čeboksary, pp. 29-50.

37 Dobrodomov, I. G. - Romanova, G. Ja. (red.) (1970): Bibliografija osnovnoj otečestvennoj literatu38 ry po izučeniju orientalizmov v vostočnoslavjanskih jazykah. In: Menges (1970, pp. $211-$ 39 238).

40 Doerfer, G. (1967): Türkische und mongolische Elemente im Neupersischen. Unter besonderer Be41 rücksichtigung älterer neupersischer Geschichtsquellen, vor allem der Mongolen- und Ti42 muridenzeit. Band III. Wiesbaden.

43 DTS: Nadeljaev, V. M.-Nasilov, D. M.-Tenišev, Ê. R.-Ščerbak, A. M. (red.): Drevnetjurkskij slovar'. Leningrad, 1969. 
1 Fasmer, M. (1986-1987): Ėtimologičeskij slovar' russkogo jazyka. 4 vols. Perevod s nemeckogo i 2 dopolnenija O. N. Trubačeva. Moskva.

3 Filin, F. P. (gl. red.) (1980): Slovar' russkogo jazyka XI-XVII vv. Vyp. 7. Moskva.

4 Gerov, N. (1976): Rečnik na bъlgarskija ezik. Čast vtora. Sofija.

5 Iudahin, K. K. (1965): Kirgizsko-russkij slovar'. Moskva.

6 Kniezsa, I. (1955): A magyar nyelv szláv jövevényszavai [The Slavic loanwords in Hungarian]. 72 vols. Budapest.

8 Komoróczy, G. (1976): A sumer-magyar nyelvrokonítás. Adalékok egy jelenség természetrajzá9 hoz [Sumerian-Hungarian language affinity. Contributions describing the nature of this 10 phenomenon]. Nyelvtudományi Közlemények Vol. 78, pp. 3-38.

11 Menges K. G. (1970): Vostočnye ėlementy v »Slove o polku Igoreve«. Leningrad.

12 Ogienko, I. I. (1915): Inojazyčnye èlementy v russkom jazyke. Kiev. Reprint: Moskva.

13 Pelliot, P. (1959): Notes on Marco Polo. Vol. I. (Ouvrage posthume, publié sous les auspices de 14 l'Académie des Inscriptions et Belles Lettres et avec le Concours du Centre National de la 15 Recherche Scientifique). Paris, pp. 145-150.

16 Radlov, V. V. (1893-1911): Opyt slovarja tjurkskih narečij. 4 vols. Sankt-Peterburg.

17 Róna-Tas, A.-Berta, Á. (2011): West Old Turkic. Turkic Loanwords in Hungarian. 2 vols. Wies18 baden

19 Sreznevskij, I. I. (1989): Slovar' drevnerusskogo jazyka. 4 vols. Reprintnoe izdanie. Moskva.

20 Šipova, E. N. (1976): Slovar' tjurkizmov v russkom jazyke. Alma-Ata.

21 TatRS (1966): Osmanov, N. N. (red.): Tatarsko-russkij slovar'. Moskva.

22 TRS (1977): Baskakov, A. N. - Golubeva, N. P.-Kjamileva, A. A. - Ljubimov, K. M. - Salimzjanova, F. A. - Jusipova, R. R. (red.): Turecko-russkij slovar'. Moskva.

24 Trubačev, O. N. (1987): Etimologičeskij slovar' slavjanskih jazykov. Vyp. 13. Moskva.

25 Uraksin, Z. G. (red.) (1996): Baškirsko-russkij slovar'. Moskva.

26 Vásáry, I. (2013): Integration of Turkic Loan Words with Final Plosives (-k/-g) into the Russian

27 Grammatical Paradigm. Turkic Languages Vol. 17, pp. 197-215.

28 Vásáry, I. (2016): Medieval Russian Terms for 'Armor' of Oriental Origin. In: Zimonyi, I. - Kara29 tay, O. (eds): Central Eurasia in the Middle Ages. Studies in Honor of Peter B. Golden. 30 Wiesbaden, pp. 435-445.

31 Zaliznjak, A. A. (2004): Drevnenovgorodskij dialekt. Vtoroe izdanie, pererabotannoe s učetom materiala nahodok 1995-2004 gg. Moskva. 